\title{
Spatial distribution of mud flows, chemoautotrophic communities, and biogeochemical habitats at Håkon Mosby Mud Volcano
}

\author{
Kerstin Jerosch $^{\mathrm{a}, *}$, Michael Schlüter ${ }^{\mathrm{a}}$, Jean-Paul Foucher ${ }^{\mathrm{b}}$, \\ Anne-Gaelle Allais ${ }^{\mathrm{b}}$, Michael Klages ${ }^{\mathrm{a}}$, Christian Edy ${ }^{\mathrm{b}}$ \\ a Alfred Wegener Institute for Polar and Marine Research, Am Handelshafen 12, 27570 Bremerhaven, Germany \\ ${ }^{\mathrm{b}}$ French Research Institute for Exploitation of the Sea (Ifremer), France
}

Received 2 February 2006; received in revised form 7 February 2007; accepted 16 March 2007

\begin{abstract}
Marine mud volcanoes are significant source locations contributing to the marine methane cycle. Enhanced heat flow, unique chemoautotrophic communities, occurrence of massive gas hydrates and large gas plumes are direct evidences of elevated methane concentrations and the dynamic environment of mud volcanoes. Related to the high concentrations and large inventories of $\mathrm{CH}_{4}$ in surface sediments only a fraction of the methane is exported to the bottom water. This is mainly due to chemoautotrophic communities oxidizing methane and proving a "microbial filter" reducing $\mathrm{CH}_{4}$ fluxes. Although these processes were studied for several mud volcanoes still little is known about the spatial pattern and the areas covered by chemoautotrophic communities or by present mud flows.

For this purposes the Håkon Mosby Mud Volcano (HMMV), which is located at the continental slope of the Barents Sea, was studied by several dives with the Remotely Operated Vehicle Victor6000. During these dives a high resolution microbathymetric map, with a footprint of $25 \times 25 \mathrm{~cm}$ and a vertical resolution of better than $10 \mathrm{~cm}$ was derived. Furthermore, video streams of the bottom camera were converted into georeferenced mosaics, providing a detailed image about the spatial distribution of seafloor features as bacterial mats, pogonophorans, both indicating methane oxidation, or mud flows. Based on visual inspection of 2310 georeferenced mosaics covering an area of $46,160 \mathrm{~m}^{2}$, different biogeochemical habitats were identified and quantified on a $\mathrm{m}^{2}$ basis. By application of geostatistic techniques as indicator kriging the distribution of different biogeochemical habitats was quantified and mapped for the entire HMMV.

Considering the flat and hummocky area of HMMV, approximately $16 \%\left(115,165 \mathrm{~m}^{2}\right)$ of the flat centre is nearly void of any benthic communities. This area is considered as a region of high methane discharge into bottom water. An area of $5 \%\left(38,244 \mathrm{~m}^{2}\right)$, located in the south-eastern part, is densely inhabited by Beggiatoa. The hummocky outer part is colonised dominantly by pogonophoran tube worms $\left(37.3 \% ; 276,121 \mathrm{~m}^{2}\right)$ and only occasional by Beggiatoa. Source locations and drainage directions for current mud flows were identified by computation of trend surfaces and consideration of temperature data. This suggests that present mud flow ascend close to the northern edge of the flat unit of HMMV, and that the drainage pattern of mud flows shifted from a westward to a south-south-eastern direction.
\end{abstract}

(C) 2007 Elsevier B.V. All rights reserved.

Keywords: mud volcano; cold seeps; methane consumption; video mosaicing; GIS; indicator kriging; habitat mapping; area estimations; trend surface

\footnotetext{
* Corresponding author. Tel.: +494714831 1261.

E-mail address: Kerstin.Jerosch@awi.de (K. Jerosch).
} 


\section{Introduction}

Mud volcanoes (MV), whether they occur onshore or offshore, are major locations of mud and fluid transfer from deep geological layers to the earth's surface. To date, more than $1700 \mathrm{MV}$ have been recorded, of which about 800 are located offshore. It is estimated that more than 10,000 exist in deep marine waters (Dimitrov, 2002; Fleischer et al., 2001; Ivanov et al., 1996; Kopf, 2002; Milkov, 2000; Milkov et al., 2003; Pimenov et al., 2000). The formation of MVs is often linked to a tectonic compression, dehydration of clay minerals at depth, or rapid deposition of mass flows as slumps or turbidites (e.g. Kopf, 2002; Huguen et al., 2004; Kohl and Roberts, 1994; Vogt et al., 1999). They frequently form mud domes with diameters of up to a few kilometers and heights of several tens of meters above adjacent seafloor.

Observations such as recent mud flows, active seepage of fluids, enhanced heat flow, unique chemoautotrophic communities, massive gas hydrates, and large gas plumes are strong evidence for elevated methane concentrations in the sediments and water column (Damm and Budéus, 2003; Sauter et al., 2006). Therefore, MVs are considered as significant source locations contributing to the marine $\mathrm{CH}_{4}$ budget.
Up to now, the Håkon Mosby Mud Volcano (HMMV), located in the Norwegian Sea, is the only active MV reported for high northern latitudes (Fig. 1). This structure was found on the continental slope of the western Barents Sea fan $\left(72^{\circ} 00.3^{\prime} \mathrm{N}\right.$ and $\left.14^{\circ} 44.0^{\prime} \mathrm{E}\right)$, within the submarine valley of Bear Island in a water depth of 1265 m (Hjelstuen et al., 1999; Vogt et al., 1997, 1999). Research cruises, including a survey by NIS Akademik Mstislav Keldysh equipped with the manned submersibles MIR-1 and MIR-2 studied the geological and geochemical settings (e.g. Milkov et al., 2004; Vogt et al., 1999). Multibeam and side-scan sonar surveys by Vogt et al. (1997, 1999) revealed the morphology and sediment textures. Biogeochemical, geophysical, and biological studies were conducted by Eldholm et al. (1999), Lein et al. (1999), Mienert and Posewang (1999), Milkov et al. (1999, 2004), Pimenov et al. (1999), and Vogt et al. (1999), among others.

At the HMMV, as on other offshore mud volcanoes, high concentrations of hydrogen sulphide and methane in the sediment offer a specific habitat for microbiological and macrofaunal associations (e.g. Hinrichs and Boetius, 2002; De Beer et al., 2006; Levin et al., 2003; Pimenov et al., 1999; Sibuet and Olu, 1998; Sibuet and Olu-Le Roy, 2002; Soltwedel et al., 2005). Sulphide-

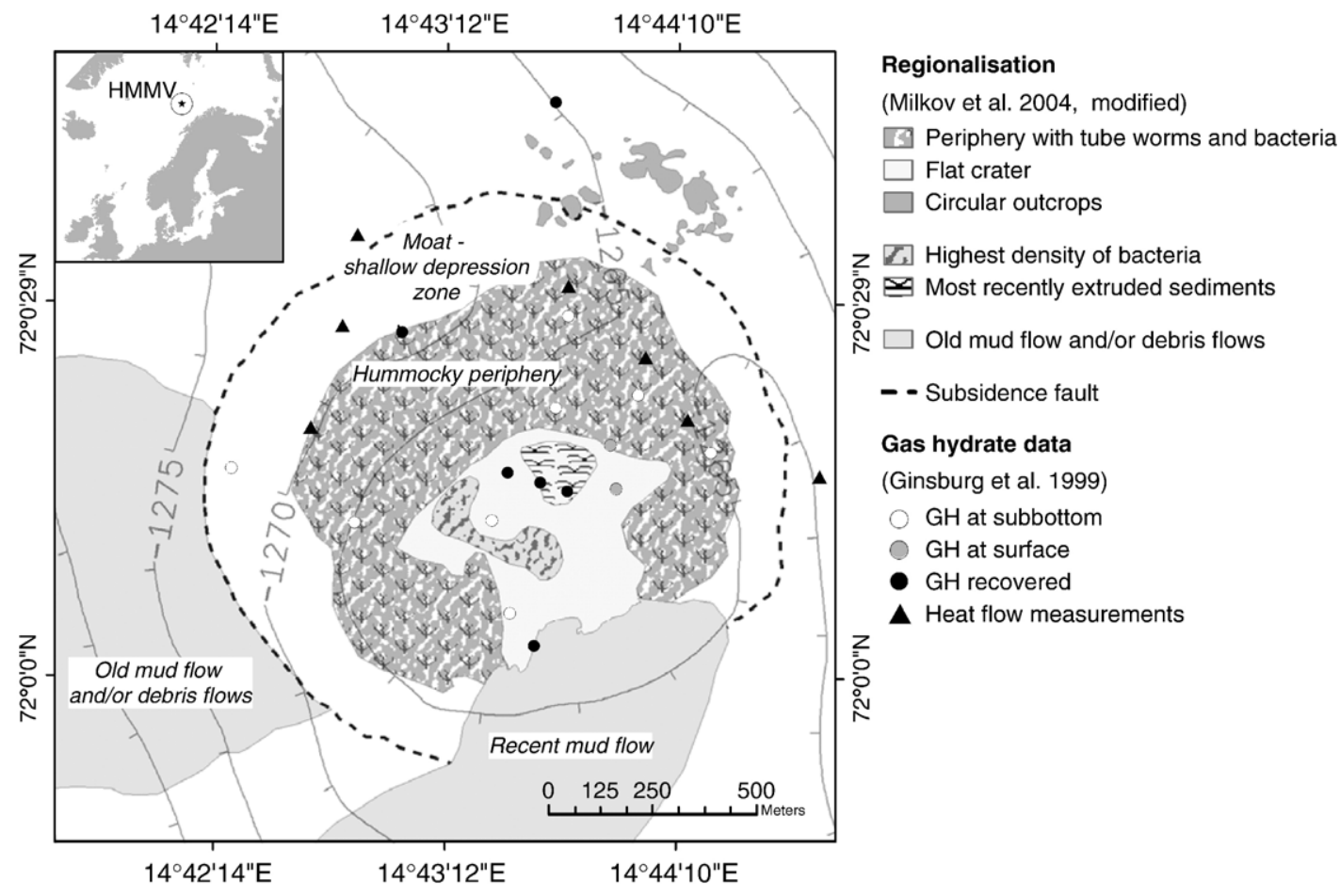

Fig. 1. Map of the Håkon Mosby Mud Volcano (HMMV) located at the continental slope of the western Barents Sea. Mud flows, observations of gas hydrates, and distribution of bacterial mats and tube worms are indicated according to studies by Eldholm et al. (1999), Ginsburg et al. (1999), Milkov et al. (2004), Smirnov (2000), and Vogt et al. (1999). 
oxidising bacteria (dominant genus Beggiatoa, e.g. Boetius et al., 2004; De Beer et al., 2006) and tube worms that rely on endosymbiotic bacteria (especially the pogonophoran species Sclerolinum contortum and Oligobrachia haakonmosbiensis) were found for example by Pimenov et al. (1999) and Gebruk et al. (2003). Sulphide mainly is produced by a microbial consortium of sulphate reducing bacteria and methane oxidising archaea (Boetius et al., 2000). This process is known as the anaerobic oxidation of methane (AOM) and provides an effective biological filter regulating the release of methane into bottom water. Subsequently, the terms Beggiatoa and pogonophorans are used as synonyms for chemoautothrophic communities, microbial consortia and associated symbionts dwelling form methane and reduced sulphur species dissolved in the pore water of sediments.

Due to anaerobic oxidation of methane, at most cold seeps and MVs methane fluxes into the water column are lower at sites covered by communities as Beggiatoa mats and pogonophoran tube worms if compared to the uncovered muds (Boetius et al., 2002; De Beer et al., 2006; Hinrichs and Boetius, 2002; Sauter et al., 2006). These chemoautotrophic communities are visual biogeochemical habitat indicators, detectable on videos and still photographs; quantification of their spatial distribution belongs to are the objectives of this study.

Although for the Håkon Mosby Mud Volcano the presence of these chemoautotrophic benthic communities was documented by towed video systems and observations by submersibles (Gebruk et al., 2003; Milkov et al., 1999), little is still known about the area covered by Beggiatoa mats and pogonophoran colonies, the mode of coverage (e.g. small spots versus patches or large mats), or their spatial relationship to mud flows and other morphological features.

For this purpose high resolution multibeam bathymetric data, still photographs, and video mosaics of the seafloor were recorded. The data were derived during dives with the remotely operated vehicle (ROV) Victor6000 (Klages et al., 2004) and integrated into a Geographic Information System (GIS). This allows for the first time a detailed analysis of spatial patterns, the quantification of biogeochemical habitats (BGH) by geostatistical methods, and an investigation of mud sequences for a mud volcano like the HMMV.

\section{Materials and methods}

During the cruise ArcXIX3b (2003) of $R V$ Polarstern, equipped with the remotely operated vehicle (ROV) Victor6000, the topography of HMMV was mapped, video observations of the seafloor were recorded, and sediment and water column samples were collected for geological and geochemical investigations. High precision underwater navigation using USBL (Ultra Short Base Line) was applied during the ROV dives and sampling. Further details on the ROV specification concerning water column and sediment sampling are reported in Klages et al. (2004).

\subsection{Microbathymetric mapping and video mosaicing}

During two ROV dives of 44 and $15 \mathrm{~h}$ bottom time the high resolution multibeam systems Reson SeaBat $8125(455 \mathrm{kHz})$ and Simrad EM2000 (200 kHz), respectively, were applied for microbathymetry mapping of HMMV. More than 250 million soundings were recorded, providing a full spatial coverage of the HMMV. Data were processed with the CARAIBES ${ }^{\circledR}$ software (Ifremer). Technical aspects of the multibeam survey and data processing are given in Edy et al. (2004) and Klages et al. (2004).

Mainly by the Reson SeaBat 8125 data a high resolution microbathymetry map with a depth resolution of better than $0.1 \mathrm{~m}$ and a footprint of $0.25 \mathrm{~m}^{2}$ at the seafloor was derived. Based on the computed digital elevation model a hill shading map was generated for improved visualisation of seafloor features as mud ridges and flow patterns (Fig. 2).

Six dives of Victor6000 were dedicated to video surveys. The ROV was navigated at about $0.3 \mathrm{~m} \mathrm{~s}^{-1}$ and at a maximum altitude of $3 \mathrm{~m}$ above seafloor. This ensured a high image quality for the vertical camera installed at the bottom of the ROV tool sled. Since the aperture of the camera is $60^{\circ}$, the width of the mosaics is about the same as the altitude of the ROV during the survey.

The video stream generated by the vertical camera along the ROV transect was processed online by the MATISSE Software ${ }^{\circledR}$. This mosaicing software, based upon image and signal processing components (Allais et al., 2004; Vincent et al., 2003), produces georeferenced mosaics (geotiffs) of the sea floor by combining the video input and Ultra Short Base Line navigation data. Each mosaic has a width of about $3 \mathrm{~m}$. The entire length of the video profiles is about $17 \mathrm{~km}$. The video mosaics were recorded and integrated into the GeoInformation-System ArcGIS (ESRI). Among the geotiffs, data published in journals and reports as well as unpublished data derived during previous cruises to HMMV were integrated into the GIS.

A total of 2310 georeferenced mosaics covering an area of $45,790 \mathrm{~m}^{2}$ were analysed by visual inspection 


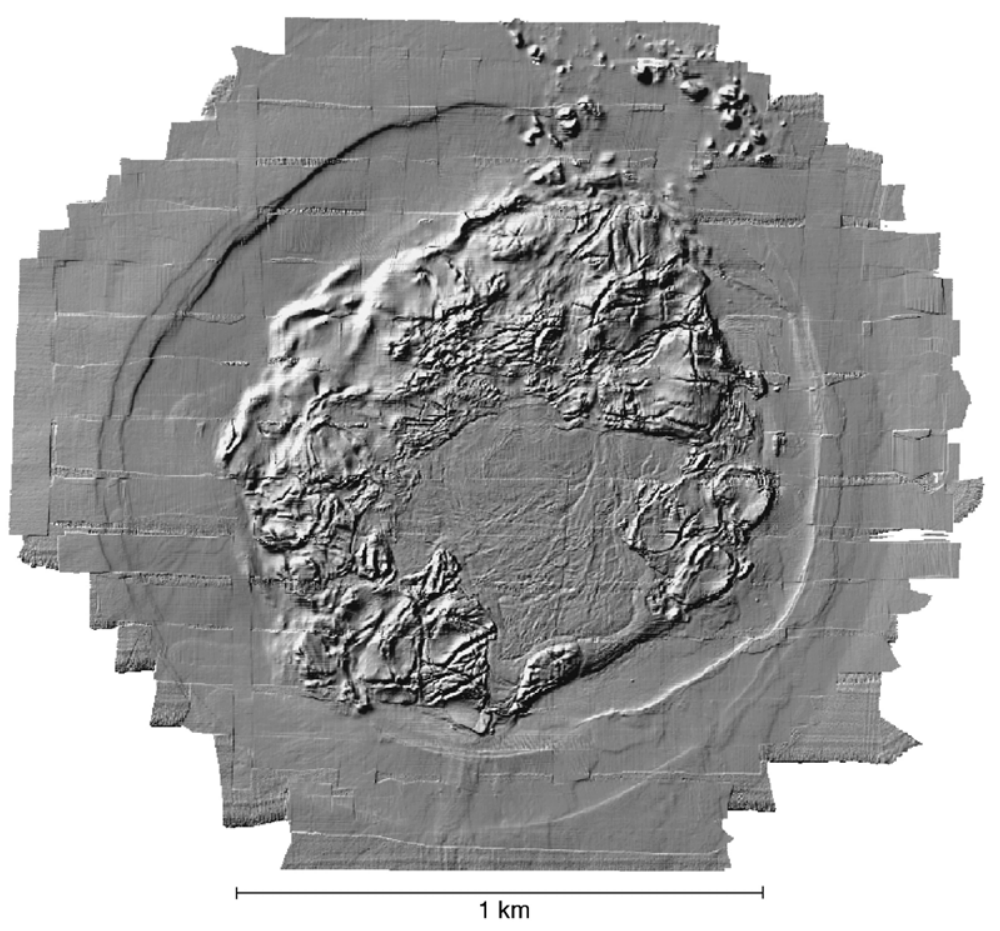

Fig. 2. Morphology of the HMMV. Microbathymetry data derived by high resolution multibeam systems operated during dives of the ROV Victor6000 are visualised as illuminated hill shading map. In total 250 million soundings were recorded. The vertical resolution of the map is better than $0.1 \mathrm{~m}$ and the footprint at the seafloor is $0.25 \mathrm{~m}^{2}$.

and GIS supported image analysis. This allows a detailed mapping of the spatial distribution of the different biogeochemical habitats which are related to the occurrence of Beggiatoa, pogonophorans, and uncovered mud. Examples of different biogeochemical habitats, characterised by the nature and density of benthic communities found on the seafloor as well as the sediment type are given in Figs. 3 and 4.

\subsection{Classification scheme for biogeochemical habitats}

The microbathymetric map derived by the multibeam data, the still photographs, and the video mosaics allows a detailed localisation and quantification of areas covered by the main spatial entities observed at HMMV. Special emphasis was placed on the determination of 1. white bacterial mats of sulphide-oxidising bacteria (dominant genus: Beggiatoa), 2. areas covered by pogonophoran tube worms, and 3 . regions of apparently uncovered mud. As a result of this visual analysis, a classification scheme was developed (Table 1). This scheme considers the main habitat indicators (HI) as occurrence of Beggiatoa, pogonophorans, or uncovered mud, the degree of coverage by benthic organisms, as well as additional observations such as seafloor tex- ture and specific features as small holes probably shaped by episodic gas release (Fig. 3f, i).

GIS supported inspection of the video mosaics revealed that in some areas the chemoautotrophic organisms are arranged as small spots whereas in other regions large patches occur. Therefore, the category "Beggiatoa mats" was subdivided in narrow spots $(\varnothing<30 \mathrm{~cm})$ and patches $(\varnothing>30 \mathrm{~cm})$. The degrees of spatial coverage by pogonophorans or Beggiatoa mats on video mosaics were grouped into the classes $<20 \%$, $20-50 \%$, and $>50 \%$ related to sub-sections of the video mosaics (Fig. 4).

Mud regions essentially uncovered by benthic biota were observed for large areas of HMMV. The texture of the sediment surface is either nearly smooth or structured by ridges and holes (Fig. 3h). According to the texture, the mud areas were classified as smooth or structured. Accompanying observations such as the occurrence of carbonate precipitates or small holes were recorded and considered within the classification scheme (Table 1). The number of small holes $(\varnothing 1-2 \mathrm{~cm})$ varies considerably and in flat parts of the hilly periphery e.g. in the southeast of the HMMV reaches up to 137 holes $/ \mathrm{m}^{2}$.

The derived classification scheme relies on a small set of accurately identifiable features without loss of 

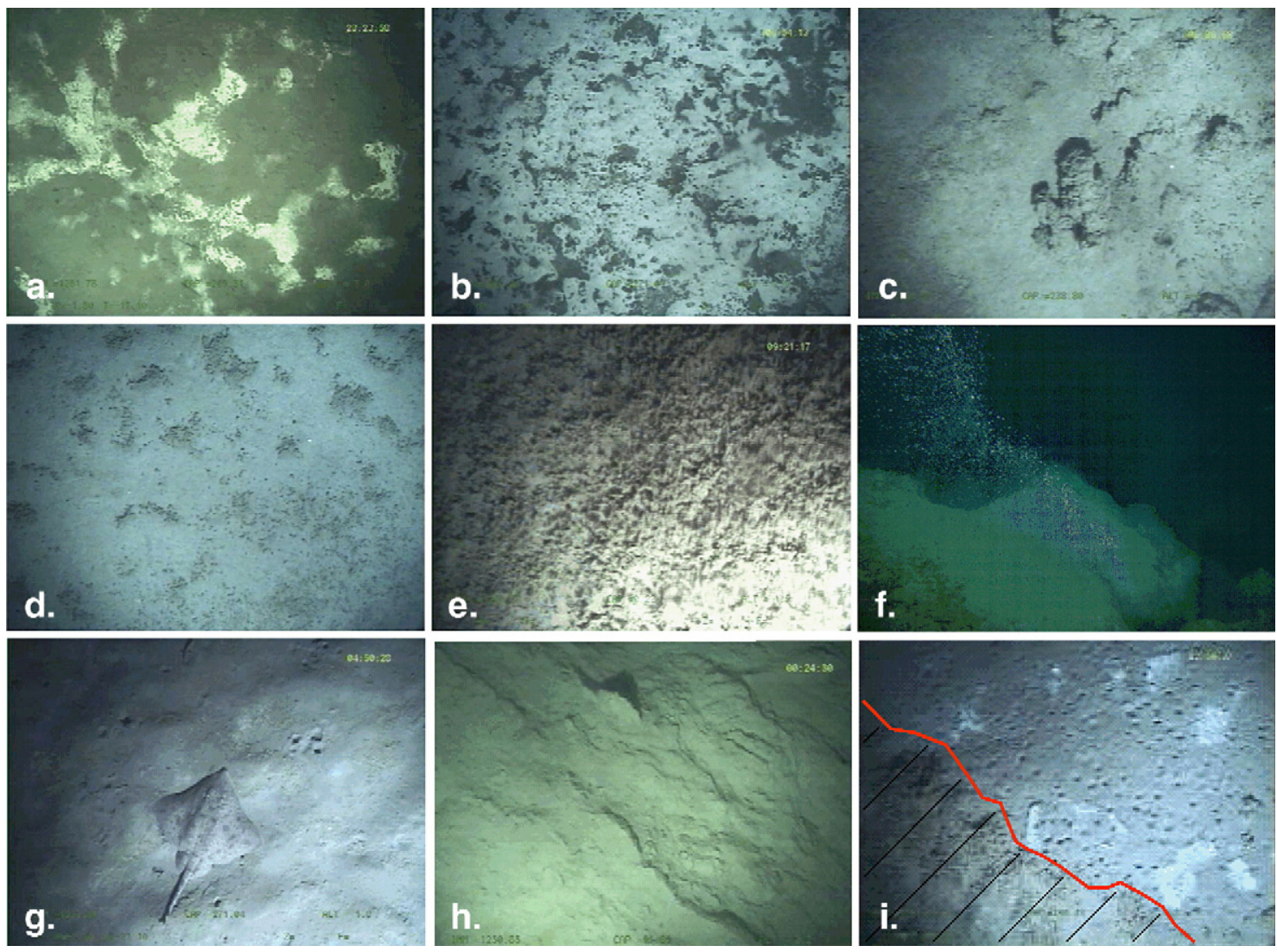

Fig. 3. Still photographs of specific features at the seafloor of HMMV: a. Beggiatoa mats (light grey) distributed as patches with a spatial coverage of $20-50 \%$ of the depicted area, b. Beggiatoa patches (dense coverage of $>50 \%$ of the area), c. authigenic carbonate crusts, d. pogonophorans (coverage $<20 \%$ ), e. pogonophorans (coverage $>50 \%$ ), f. active venting and release of free methane gas from the seafloor, g. smooth mud, with small holes (ray resting on seafloor), h. structured mud, and i. pogonophorans (lower left) and small holes (upper right).

essential information. Based on the video mosaics, these classes were identified and digitized as polygons within the GIS. For each polygon, the geometry (e.g. diameter and perimeter), the area, and the habitat category are computed and stored. In total, more than 1722 polygons were identified and determined coming from 2310 analysed geotiffs.

\subsection{Geostatistics: indicator kriging}

Geostatistical techniques such as variogram analysis and kriging are commonly applied in oil, gas and mineral exploration, in groundwater research, and for marine or terrestrial habitat mapping (e.g. BonhamCarter, 1996; Isaaks and Srivastava, 1992; Rivoirard and Wieland, 2001; Schlüter, 1996). These techniques allow the computation of regional patterns and contour plots under consideration of the spatial distribution of the input data. Based on the visual interpretation of the entire set of video mosaics different, habitats were identified and digitised as polygons (Figs. 4 and 5). The dense coverage of video mosaics allows the application of indicator kriging (IK), variogram analysis and, therefore, the computation of surface maps covering almost the entire mud volcano.

The results of the geostatistical analysis were validated by calculation of standard errors of prediction and by cross-validation. In this statistical technique, raw data are removed from the entire data set. This artificially reduced data set is the input for a new variogram analysis and IK, which now predicts values for coordinates where data (which were not part of the analysis) are available. Comparison between available raw data and predicted values expresses the accuracy of computed maps (Jerosch et al., 2006).

The result of the variogram analysis and IK is visualised as single maps for each of the three major habitat types: 1. areas of uncovered, structured and smooth mud sequences; 2 . regions covered mainly by pogonophorans; and 3 . regions mainly covered by 

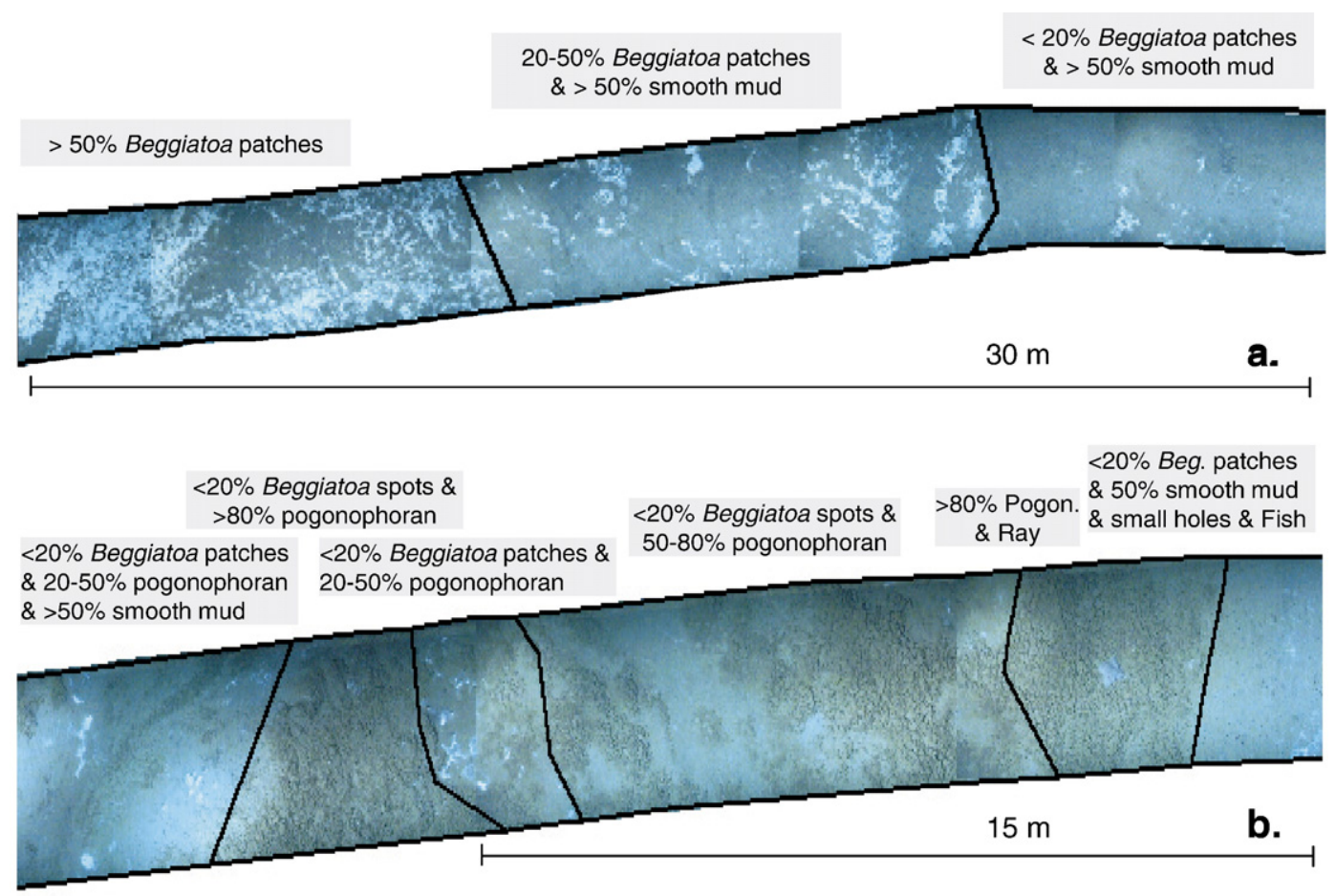

Fig. 4. Video-mosaics derived during ROV dives. a. Mosaics presenting a sequence (left to right) from a dense coverage by Beggiatoa to essentially uncovered mud. b. Mosaics showing a transition zone from Beggiatoa to pogonophorans and uncovered mud. By visual inspection of the video mosaics different sub-sections were identified following the classification scheme and indicated by polygons bordered by black lines within GIS.

Beggiatoa (Fig. 6a-c). These three maps were aggregated to one by overlay technique within the GIS. This supports visualisation of the complex distribution of the distinct biogeochemical habitats (Fig. 6d). Combining spatial information as microbathymetry (Fig. 2), visual interpretation of video mosaics (Fig. 4), maps on slope direction (Fig. 5), and geostatistical analysis allows

Table 1

Classification scheme of habitat indicators (HI), derived by visual inspection of video mosaics and still photographs (Figs. 3 and 4) for the HMMV

\begin{tabular}{lllll}
\hline Habitat indicator $(\mathrm{HI})$ & \multicolumn{4}{l}{ Coverage degree } \\
\cline { 2 - 5 } & $(\%)$ & & & \\
\hline Pogonophorans & $<20$ & $20-50$ & $>50$ & \\
Beggiatoa patches $(\varnothing>30 \mathrm{~cm})$ & $<20$ & $20-50$ & $>50$ & \\
Beggiatoa spots $(\varnothing<30 \mathrm{~cm})$ & $<20$ & $20-50$ & $>50$ & \\
Uncovered mud (smooth) & & & $>50$ & 100 \\
Uncovered mud (structured) & & & $>50$ & 100
\end{tabular}

Accompanying observations (AO) $\quad$ Relief, large holes $(\varnothing<15-$

$20 \mathrm{~cm})$, small holes $(\varnothing<1-$

$2 \mathrm{~cm})$, carbonate crusts,

demersal fish as eelpouts

(Zoarcidae) and rays estimating the coverage of HMMV by different biogeochemical habitats.

\section{Results}

\subsection{Quantification of morphological units}

The high resolution microbathymetric data (Fig. 2) allows a detailed identification and quantification of three major morphological features of HMMV: I. the flat area in the centre and the southeast, II. the hummocky periphery, and III. the moat area including circular outcrops (Figs. 2 and 5). The latter is a shallow depression surrounding the hummocky periphery. The entire area of the HMMV (eHMMV), units I, II and III, is almost circularly limited by subsidence faults, has a diameter of $1365 \mathrm{~m}$ in N/S and $1380 \mathrm{~m} \mathrm{~W} / \mathrm{E}$ direction, and covers a total area of 1,395,532 $\mathrm{m}^{2}$.

The flat area (unit I) in the centre of HMMV is located in a water depth of $1255 \mathrm{~m}$ to $1259 \mathrm{~m}$, has a diameter of 400 to $500 \mathrm{~m}$, and is formed by recent mud flows. It is enclosed by a hummocky peripheral rim (unit II) with a maximum width of $440 \mathrm{~m}$ in the north, $350 \mathrm{~m}$ in the west, and $150 \mathrm{~m}$ in the east. In the SE the hummocky peripheral rim is rather narrow and has a minimum width of only $10 \mathrm{~m}$. 
The hummocky region shows a maximum height of only $9 \mathrm{~m}$ in relation to the centre and at most $16 \mathrm{~m}$ relative to the surrounding moat area of the mud volcano. In the southeast the fresh mud flow replaces the hummocky structure partially, indicating the direction of recent mud flows (Fig. 2). The third unit, a circular $2 \mathrm{~m}$ deep moat of 100 to $270 \mathrm{~m}$ width surrounds the hummocky unit. In the NE this moat is partly interrupted by small circular outcrops (10 to $30 \mathrm{~m}$ in diameter) exceeding the mud volcano structure.

Units I and II are the regions where chemoautotrophic communities, mud flows, enhanced geothermal gradients, high $\mathrm{CH}_{4}$ concentration in sediments, seepage of $\mathrm{CH}_{4}$ bubbles, and gas hydrates were observed. This very active area, related to the $\mathrm{CH}_{4}$ cycle, of unit I and II is referred as the high $\mathrm{CH}_{4}$ region (HCR) of HMMV, subsequently. The HCR covers an area of $739,729 \mathrm{~m}^{2}$ ( $53 \%$ of the eHMMV) and forms the reference area for the surface calculation in the following. In N/S and E/W direction the diameter of the HCR is $1000 \mathrm{~m}$ and $1050 \mathrm{~m}$, respectively. The maximum diameter of the HCR, $1160 \mathrm{~m}$, is observed in SW/NE direction.

Besides these characteristic units, the hill shading map visualises the general lineation pattern as rims and ridges on the sediment surface (Fig. 2). The dominant orientation of these lineations is in NE to SW direction. Several E to W oriented lineations are obvious in the northern part. The mud sequence in the central part of HMMV seems to be structured by distinct flow lines.

The accuracy of the high resolution bathymetry allows the computation of elevation profiles (Fig. 5) and calculation of slope angles for the different units (Tables 2 and 3). This spatial analysis reveals that the central flat region has an area of $192,527 \mathrm{~m}^{2}(26 \%$ of the HCR or $13.8 \%$ of the eHMMV) and is characterised by low inclination values of generally less than $3^{\circ}$ (mean value: $2.0^{\circ}$ ). Only in the southwest of unit I a few areas show values up to $5^{\circ}$ (mean value: $3.5^{\circ}$ ) due to local undulations. Nevertheless, Fig. 2 reveals that these areas stand out clearly from the slope inclinations of the hummocky unit II and are thus assigned to unit I.

The mud layer in the centre seemed to be subdivided by rims or terraces (Fig. 3h) caused probably by individual sequences of mud flows. We assume that these regions are indicating the temporal sequence and pathways of mud flows and their interaction with the hummocky landscape, for example, mud flows terminated at hummocky structures in the south and the southeast (Fig. 2).

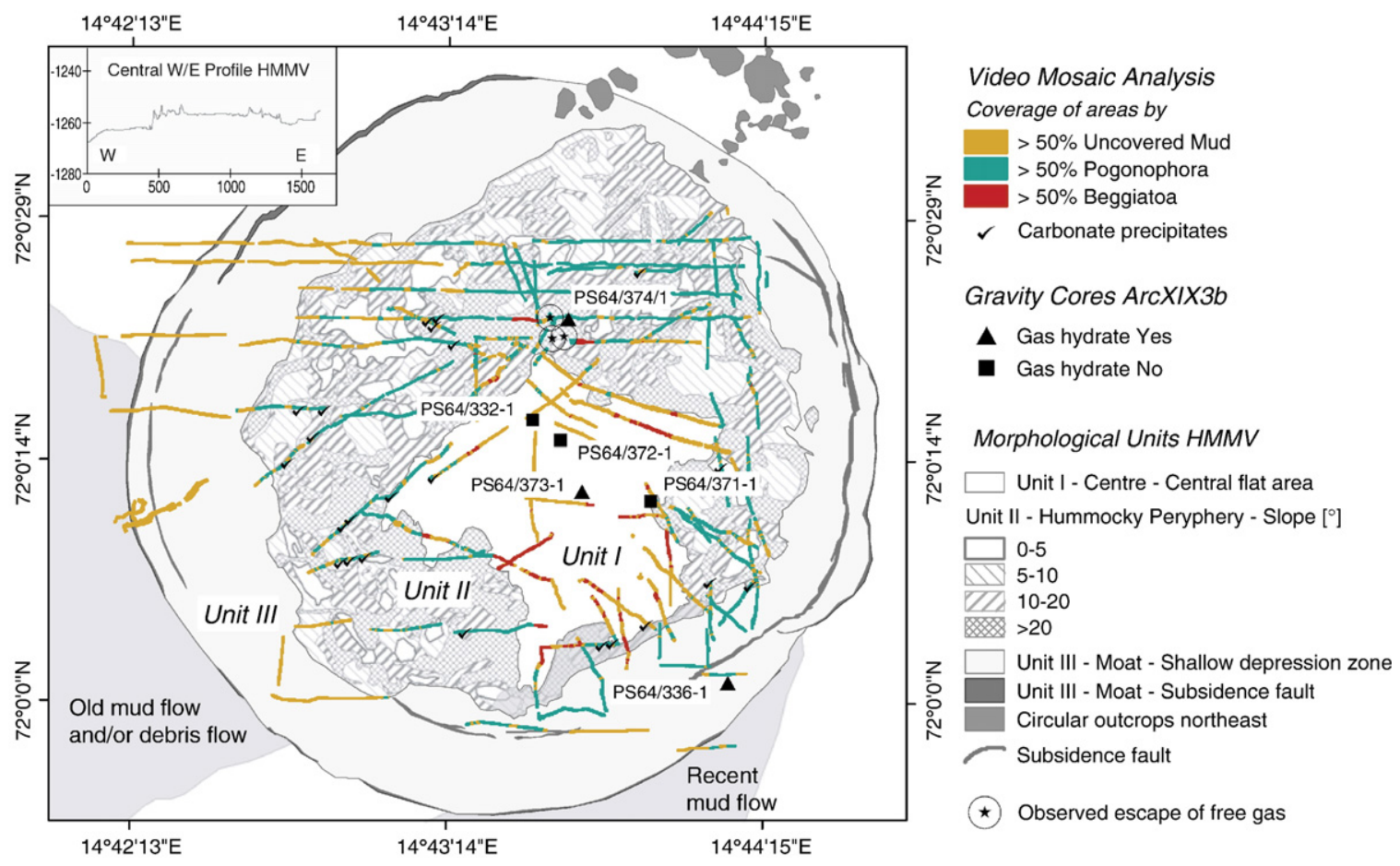

Fig. 5. Major morphological units of the HMMV derived by microbathymetric data and computed hill shading map (Fig. 4-2): centre (unit I), hummocky peripheral rim (unit II) and moat area (unit III). The area of these three units is defined as the entire area of the HMMV (eHMMV). Subsidence faults (black, nearly circular lines) limit the eHMMV from the surrounding seafloor. Tracks of video mosaicing survey are indicated by coloured lines. The red, green, and brown lines indicate areas covered by more than 50\% with Beggiatoa mats, pogonophorans or areas of unsettled mud, respectively. Unit I and II are reflected as the high $\mathrm{CH}_{4}$ region (HCR). 

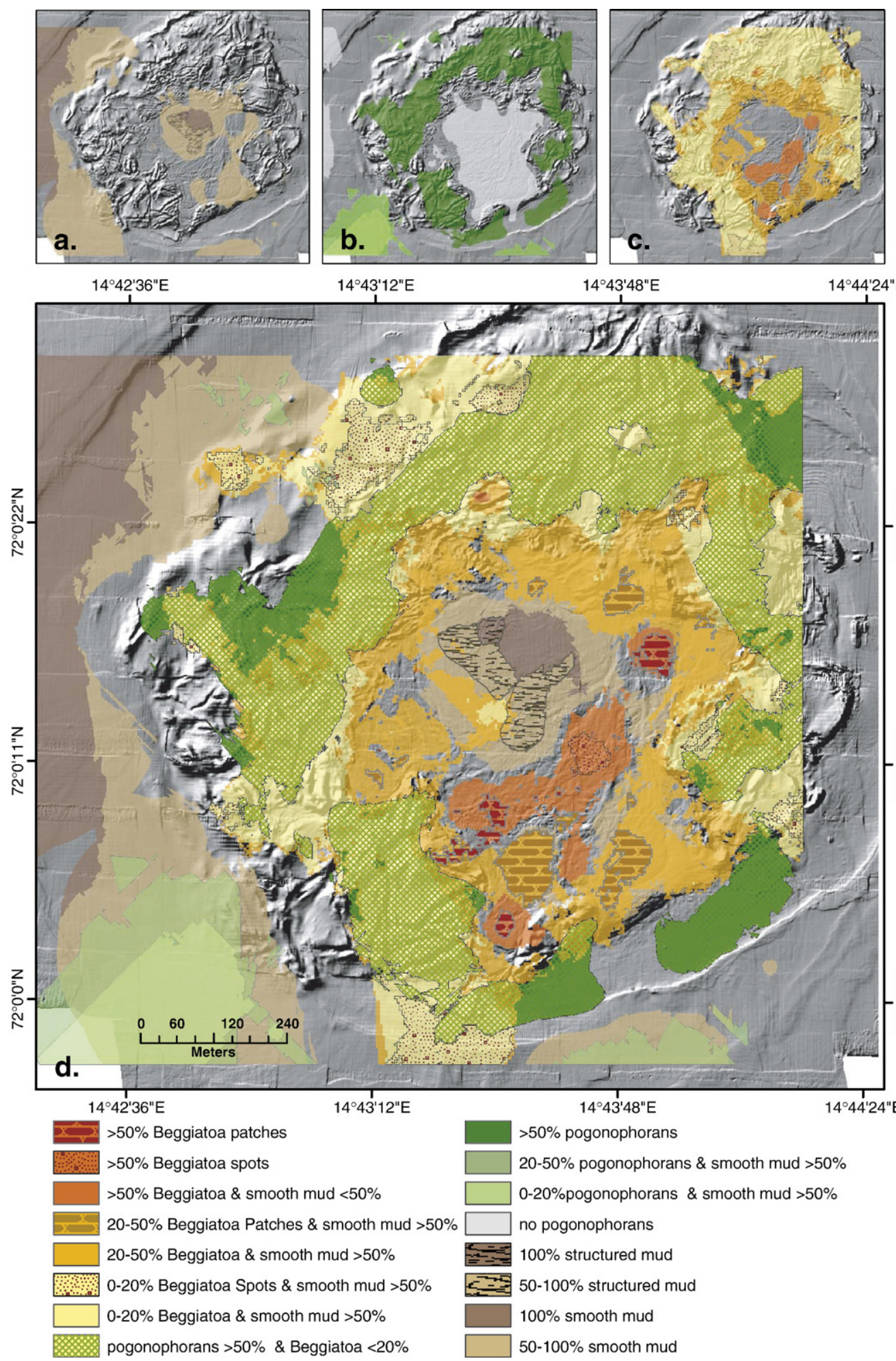

$14^{\circ} 43^{\prime} 12^{\prime \prime} \mathrm{E} \quad 14^{\circ} 43^{\prime} 48^{\prime \prime}$

$14^{\circ} 44^{\prime} 24^{\prime \prime} E$
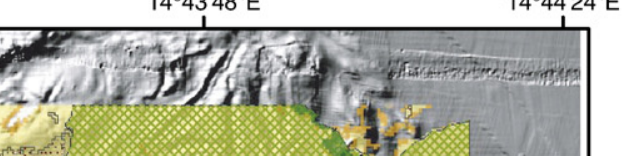
Table 2

Slope inclinations and areas of the main morphologic units at the HMMV

\begin{tabular}{|c|c|c|c|c|c|c|}
\hline & \multirow[b]{2}{*}{ Unit I } & \multirow[b]{2}{*}{ Unit II } & \multirow{2}{*}{$\frac{\text { High } \mathrm{CH}_{4} \text { region }(\mathrm{HCR})}{\text { Unit } \mathrm{I}+\mathrm{II}}$} & & & \multirow{2}{*}{$\frac{\text { Entire HMMV (eHMMV) }}{\text { Unit I+II+III }}$} \\
\hline & & & & \multicolumn{2}{|l|}{ Unit III } & \\
\hline & Central flat area & Hummocky periphery & Sum $\left(\mathrm{m}^{2}\right) \mathrm{HCR}$ & Moat area & Circular outcrops in NE & Sum $\left(\mathrm{m}^{2}\right)$ eHMMV \\
\hline & $\left(\mathrm{m}^{2}\right)$ & $\left(\mathrm{m}^{2}\right)$ & & $\left(\mathrm{m}^{2}\right)$ & $\left(\mathrm{m}^{2}\right)$ & \\
\hline \multicolumn{7}{|l|}{ Slope $\left[{ }^{\circ}\right]$} \\
\hline $0-5$ & 144,284 & - & 144,284 & 612,182 & - & 756,466 \\
\hline $5-10$ & 48,243 & 139,808 & 188,051 & $17,485^{*}$ & - & 205,536 \\
\hline $10-20$ & - & 205,021 & 205,021 & $7065^{*}$ & 9552 & 221,637 \\
\hline$>20$ & - & 202,373 & 202,373 & $2037^{*}$ & 16,584 & 220,993 \\
\hline $\operatorname{Sum}\left[\mathrm{m}^{2}\right]$ & 192,527 & 547,202 & 739,729 & 629,667 & 26,136 & $1,395,532$ \\
\hline $\operatorname{HCR}[\%]$ & 26.03 & 73.97 & 100 & & & \\
\hline eHMMV [\%] & 13.8 & 39.21 & & 45.12 & 1.87 & 100 \\
\hline
\end{tabular}

For the moat region slopes of $>5^{\circ}$ (marked by *) were observed in the direct vicinity of fault lineations (Fig. 5). The HCR region comprises of HMMV units I and II, the eHMMV of units I, II and III.

The total area of the hummocky peripheral rim is $547,202 \mathrm{~m}^{2}(74 \%$ of the HCR or $39.2 \%$ of the eHMMV), thus more than 2.5 times larger than the flat mud region in the centre of the HMMV. Large slope inclinations of more than $20^{\circ}$ are typical. A maximum slope angle of more than $50^{\circ}$ was found at lineations distributed regularly in the hummocky area. For both the flat area in the centre and the hummocky peripheral rim the calculated slope angles coincide well with the visual observations obtained during dives by Victor6000; especially in the northern part steep slopes and escarpments were obvious.

The third unit, the shallow depression zone surrounding the HMMV, has a size of $612,182 \mathrm{~m}^{2}(43.9 \%$ of eHMMV) and rather low inclinations of less than $1.5^{\circ}$ (mean value: $1.4^{\circ}$ ). The abrupt transition between the hummocky region and the moat area was also visually confirmed during the ROV surveys.

\subsection{Spatial distribution of biogeochemical habitats}

Image analysis showed that $21,567 \mathrm{~m}^{2}(47.1 \%)$ of the observed area $\left(45,790 \mathrm{~m}^{2}\right)$ is densely, by more than $50 \%$, colonised by pogonophorans. In contrast, with $2290 \mathrm{~m}^{2}(5 \%)$ a much smaller area is densely $(>50 \%)$ colonised by bacterial mats. The mud area, essentially uncovered by bacterial mats or pogonophorans, covers $21,933 \mathrm{~m}^{2}(47.9 \%)$ of the investigated region. $6460 \mathrm{~m}^{2}$ of this uncovered area is located outside of the HCR (Fig. 5).

Since the video surveys cover a significant part of the $\mathrm{MV}$, these calculated areas are considered as robust

Table 3

Summary of the microbathymetry analysis: minimum, maximum and mean bathymetric values concerning the morphologic units, together with variances and the average slope inclination

\begin{tabular}{|c|c|c|c|c|c|c|}
\hline \multirow[t]{3}{*}{ Morphologic units } & & \multicolumn{4}{|c|}{ Bathymetry } & \multirow{3}{*}{$\frac{\frac{\text { Slope }}{\left(^{\circ}\right)}}{\text { Mean }}$} \\
\hline & & \multicolumn{4}{|l|}{$(\mathrm{m})$} & \\
\hline & & Min & Max & Diff. & Mean & \\
\hline \multirow[t]{3}{*}{ Central flat area (unit I) } & $0-5^{\circ}$ & -1258.7 & -1254.9 & 3.8 & -1256.8 & 2.0 \\
\hline & $5-10^{\circ}$ & -1259.2 & -1254.7 & 4.5 & -1257.0 & 3.5 \\
\hline & Entire I & -1259.2 & -1254.7 & 4.5 & -1257.0 & 2.4 \\
\hline \multirow[t]{5}{*}{ Hummocky area (unit II) } & $0-5^{\circ}$ & -1263.2 & -1254.1 & 9.1 & -1258.7 & 2.7 \\
\hline & $5-10^{\circ}$ & -1266.0 & -1257.6 & 8.4 & -1261.1 & 4.7 \\
\hline & $10-20^{\circ}$ & -1265.3 & -1250.0 & 15.3 & -1257.7 & 6.8 \\
\hline & $>20^{\circ}$ & -1265.5 & -1250.0 & 15.5 & -1257.8 & 13.6 \\
\hline & Entire II & -1266.0 & -1250.0 & 16.0 & -1258.0 & 8.2 \\
\hline \multirow[t]{3}{*}{ Moat area (unit III) } & $0-5^{\circ}$ & -1266.3 & -1257.2 & 9.1 & -1261.8 & 1.4 \\
\hline & $5-10^{\circ}$ & -1264.7 & -1257.3 & 7.4 & -1261.0 & 5.6 \\
\hline & Entire III & -1266.3 & -1257.2 & 9.1 & -1261.8 & 1.6 \\
\hline
\end{tabular}


estimates for the spatial distribution of biogeochemical habitats of the HCR. A step beyond interpretation of these observations is provided by geostatistical analysis. Variogram analysis and indicator kriging allow generating area-wide prediction especially for the HCR (Fig. 6, Table 5).

Fig. $6 \mathrm{a}-\mathrm{c}$ show the spatial distribution of uncovered mud and of dense population by pogonophorans or bacterial mats. Visual inspection of the seafloor images reveals a high coverage by bacterial mats for the outer rim of the flat central area (Fig. 6c) whereas pogonophorans cover large regions of the hummocky periphery (Fig. 6b). The regions of uncovered mud can be subdivided into two settings: 1 . the flat centre of the crater and 2. the moat region enclosing the hummocky periphery (Fig. 6a). This general pattern, already

Table 4

Areas covered by the different chemoautotrophic communities and uncovered mud regions according to a geostatistical calculation of three mono-parametric maps

\begin{tabular}{|c|c|c|c|}
\hline \multirow[t]{2}{*}{ a. } & Area & \multirow[t]{2}{*}{$\%$ of coverage } & \multirow[t]{2}{*}{ HI Beggiatoa } \\
\hline & $\left(\mathrm{m}^{2}\right)$ & & \\
\hline \multirow[t]{8}{*}{ Beggiatoa } & 6809 & 0.9 & $>50 \%$ patches \\
\hline & 2357 & 0.3 & $>50 \%$ spots \\
\hline & 29,078 & 3.9 & $>50 \%$ \\
\hline & 22,699 & 3.1 & $20-50 \%$ patches \\
\hline & 43,815 & 5.9 & $20-50 \%$ spots \\
\hline & 163,077 & 22.1 & $20-50 \%$ \\
\hline & 250,200 & 33.8 & $0-20 \%$ \\
\hline & 88,099 & 11.9 & No occurrence \\
\hline$\sum$ for $>50 \%$ & 38,244 & 5.2 & \\
\hline$\sum$ & 606,134 & 81.9 & \\
\hline \multirow[t]{2}{*}{ b. } & Area & $\%$ of coverage & HI Pogonophoran \\
\hline & $\left(\mathrm{m}^{2}\right)$ & & \\
\hline \multirow[t]{4}{*}{ Pogonophorans } & 276,121 & 37.3 & $>50 \%$ \\
\hline & 43,295 & 5.9 & $20-50 \%$ \\
\hline & 36,649 & 5.0 & $0-20 \%$ \\
\hline & 297,746 & 40.3 & No occurrence \\
\hline$\sum$ for $>50 \%$ & 276,121 & 37.3 & \\
\hline $\bar{\Sigma}$ & 653,811 & 88.5 & \\
\hline \multirow[t]{2}{*}{ c. } & Area & $\%$ of coverage & HI Mud \\
\hline & $\left(\mathrm{m}^{2}\right)$ & & \\
\hline \multirow[t]{4}{*}{ Mud } & 8286 & 1.1 & $100 \%$ smooth \\
\hline & 1182 & 0.2 & $100 \%$ structured \\
\hline & 93,441 & 12.6 & $>50 \%$ smooth \\
\hline & 12,256 & 1.7 & $>50 \%$ structured \\
\hline$\sum$ for $>50 \%$ & 115,165 & 15.6 & \\
\hline$\sum$ & 115,165 & 15.6 & \\
\hline
\end{tabular}

The percentage of coverage is related to the HCR of the HMMV (units I and II: $739,729 \mathrm{~m}^{2}$ ): a. Beggiatoa, b. pogonophorans, c. mud. The values in $\mathrm{a}-\mathrm{c}$ of this table correspond with the areas in the monoparametric maps in Fig. 6a-c.
Table 5

Area and coverage degrees of the habitat indicators (HI) referred to the high $\mathrm{CH}_{4}$ region (HCR) $\left(739,729 \mathrm{~m}^{2}\right)$

\begin{tabular}{|c|c|c|c|c|}
\hline \multicolumn{3}{|c|}{ Habitat indicator $(\mathrm{HI})$} & \multirow{2}{*}{$\frac{\text { Area }}{\left(\mathrm{m}^{2}\right)}$} & \multirow{2}{*}{$\begin{array}{l}\% \text { of } \\
\text { coverage }\end{array}$} \\
\hline Beggiatoa & & Pogonophorans & & \\
\hline$>50 \%$ patches & $\&$ & no occurrence & 6809 & 0.9 \\
\hline$>50 \%$ spots & $\&$ & no occurrence & 2357 & 0.3 \\
\hline$>50 \%$ & $\&$ & no occurrence & 22,269 & 3 \\
\hline $20-50 \%$ patches & $\&$ & no occurrence & 21,687 & 2.9 \\
\hline $20-50 \%$ & $\&$ & no occurrence & 35,093 & 4.7 \\
\hline $0-20 \%$ spots & $\&$ & no prediction & 30,185 & 4.1 \\
\hline $0-20 \%$ & $\&$ & $>50 \%$ & 167,329 & 22.7 \\
\hline $0-20 \%$ & $\&$ & no prediction & 82,127 & 11.1 \\
\hline No occurrence & $\&$ & $>50 \%$ & 61,013 & 8.3 \\
\hline No occurrence & $\&$ & $0-20 \%$ & 26,436 & 3.6 \\
\hline No occurrence & $\&$ & $20-50 \%$ & 21,333 & 2.9 \\
\hline No occurrence & $\&$ & no occurrence & 115,165 & 15.6 \\
\hline & & & 591,803 & 80 \\
\hline
\end{tabular}

The table gives a subset of the results after an application of GIS overlay technique using the mono-parametric maps (Beggiatoa and pogonophorans) and corresponds to Fig. 6d.

reported by Milkov et al. (1999) and Gebruk et al. (2003), can be improved by the georeferenced video mosaics to a more detailed spatial analysis of the HMMV habitats. This spatial analysis allows to calculate areas as well as to decipher the degree of coverage by chemoautotrophic organisms dwelling on methane and sulphur fluxes from below.

Based on the three mono-parametric maps (Fig. 6a-c) areas covered by chemoautotrophic communities and uncovered mud were calculated. These area calculations, referring to the three mono-parametric maps, are given in Table 4 . The spatial analysis revealed that $31,435 \mathrm{~m}^{2}(4.2 \%$ of the HCR $)$ is densely covered $(>50 \%)$ by Beggiatoa mats and a considerable larger area of $275,958 \mathrm{~m}^{2}(37.3 \%$ of the HCR) is densely covered by pogonophorans. In the centre of the mud volcano an area of $115,165 \mathrm{~m}^{2}(15.6 \%$ of the HCR $)$ is not or only very scarcely colonised by larger $\mathrm{CH}_{4}$ indicating micro- and macrofauna of Beggiatoa and pogonophorans.

By combining the three information layers (Fig. 6a-c) into a single map by GIS overlay technique the complex habitat distribution at the HMMV can be identified (Fig. 6d). Based on Table 5 and Fig. 6d the combined populated areas (Beggiatoa and pogonophorans) can be quantified and assigned to sub-regions of the high $\mathrm{CH}_{4}$ bearing region (HCR).

Mud areas essentially uncovered by any chemoautotrophic organism are observed in the centre and the SE of the HMMV (Fig. 6a). Whereas the major part of the mud surface is rather smooth and unstructured, an area 
surrounding the central part is structured by hollows and rims as in Fig. 3h. This structured mud is mainly stretching from the centre to the E and S of the centre (Fig. 6d).

Whereas a few regions in the central, rather flat part of the HMMV are covered densely by Beggiatoa, no pogonophorans were observed in this region (Fig. 6b). The pogonophorans are essentially restricted to the hummock periphery. Furthermore, this chemoautotrophic community is observed outside the moat subsidence faults in the S and SW of the HMMV.

Except for the central part of the HMMV, where smooth or structured mud is observed, bacterial mats are spread almost over the entire HCR (Fig. 6c). Especially the region south of the structured mud is densely (by more than 50\%) covered by Beggiatoa mats which occur on smooth mud areas.

The association "Beggiatoa mats with smooth mud" is also observed for the moat area in the S and NNW of the HMMV. Even in the hummocky periphery (morphological unit II) bacterial mats were observed. With $167,329 \mathrm{~m}^{2}$ a large area (22.6\%) of the hummocky area is settled by pogonophora ( $>50 \%$ coverage) and $\mathrm{Beg}$ giatoa $(<20 \%$ coverage) (Fig. 6d, Table 5 ).

\section{Discussion}

The microbathymetry map derived by the high resolution multibeam systems (footprint of $0.25 \mathrm{~m}^{2}$ ) and the video mosaics compiled during the ROV dives, provides a detailed insight into the morphology and distribution of mud flows and chemoautotrophic communities. This allows to identify seabed structures with only a few centimeters of elevation, the computation of a digital elevation model, or to derive a map on slope direction. Therefore, relations between geomorphologic structures and biogeochemical habitats, observed on georeferenced video mosaics, can be identified.

For spatial analysis of seafloor features such as the degree of coverage by benthic organisms or of sediment properties, video mosaicing provides several advantages compared to still photographs. Since they are georeferenced, their coordinates and extent - on a $\mathrm{m}^{2}$ basis - is known, and the area of even small scale features can be measured accurately and related to bathymetry and other features. Whereas adjacent still photographs of the seafloor might overlap, bearing the risk of overestimating spatial extents, this overlap is eliminated by the video mosaicing algorithm. Since the mosaics provide a continuous cover of considerably larger areas than still photographs, regional transitions from scarce to dense population by Beggiatoa mats or from smooth to structured mud can be identified and quantified (Fig. 4).
Compared to the size of the eHMMV (approx. $1.4 \mathrm{~km} \times 1.4 \mathrm{~km}$ ), which is comparable to other offshore mud volcanoes (Kopf, 2002; Milkov, 2000), the spatial coverage by video mosaics is rather high (Fig. 5). In addition to the interpolation of the mosaics, we applied variogram analysis and indicator kriging to derive maps about the distribution of different biogeochemical habitats for the entire area of the HMMV. In general, spatial interpolation provides local estimates. Statistical techniques, maps on standard deviations, semi-variogram analysis, and cross-validation, allow to evaluate the accuracy of such linear estimates and are suitable to optimise the spatial interpolation process (Clark, 1982), one reason to apply kriging.

Furthermore, the applied IK deals with the data heterogeneity according to a scientific question to be studied (Goovaerts, 1997); for example, investigating and predicting the probability of the occurrence of an organism at a certain place at the seafloor. The determination of the areas shown in Fig. 6 is based on a defined threshold of occurrence probability of each HI, respectively (Jerosch et al., 2006). For our data set statistical mean values resulting from the cross-validation and the comparison between observed values and predicted values, revealed similarities of better than $83 \%$. Particularly good results were obtained with the forecast of uncovered mud areas ( $>89 \%)$, regions with more than $50 \%$ bacteria coverage $(>92 \%)$ and areas covered to $0-20 \%$ by pogonophorans ( $>90 \%$ ).

The microbathymetry data and hill shading map (Fig. 2) allow interpretation of the sequence of mud flows. Mud flows identified by interpretation of sidescan sonar images were heading in westerly (old mud flow) and southern (young mud flow) direction (Milkov et al., 2004; Vogt et al., 1997). This is confirmed by the multibeam microbathymetric data (Fig. 2), showing a lobe-shaped, $2 \mathrm{~m}$ high elevation within the western and the southern moat subsidence zone.

A more detailed consideration of flow direction and possible source location of current mud flows within the HCR can be derived by microbathymetric data and temperature measurements. For this purpose trend surface analysis was applied to bathymetric data obtained for the surrounding, the western flank of the submarine valley, of HMMV and the microbathymetric data measured for unit I (Fig. 7). By trend surface analysis (Davis, 2002), small scale undulation can be leveled out to decipher the general trend of sediment layers. This technique, is used in oil and mineral exploration, hydrogeology, or structural geology for identification of strike or slip directions of subsurface strata or drainage patterns. The high resolution 

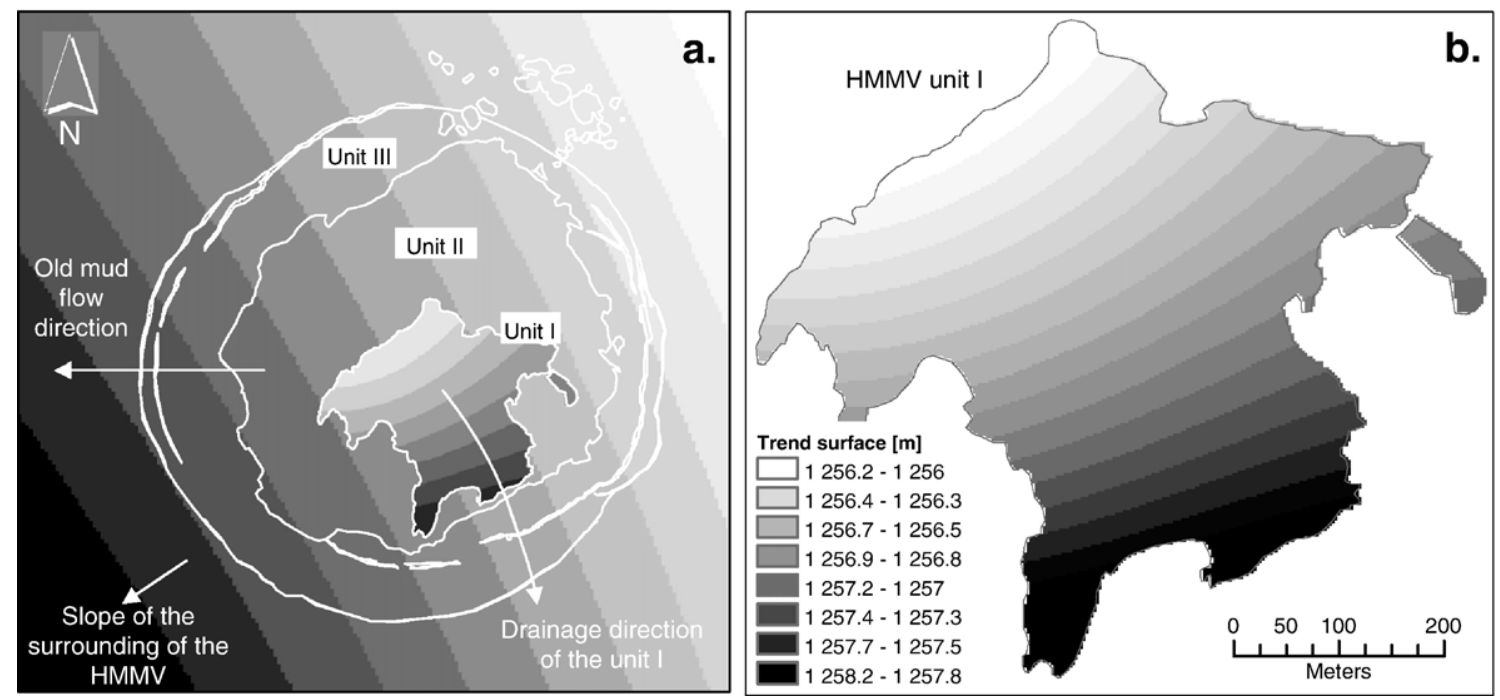

Fig. 7. Polynomial trend surfaces a. using bathymetric data ( $R V$ Polarstern) from the HMMV and its surrounding and b. applying microbathymetry data (Victor6000) for the HMMV unit I. Composition of both analyses reveals that the slope direction of unit I is perpendicular to the slope of the surrounding of the HMMV.

microbathymetry data (footprint of $0.5 \times 0.5 \mathrm{~m}$ ) allows calculation of trend surfaces without bias of undersampling and aliasing effects.

The surrounding of the HMMV, located in a submarine valley at the Barents Sea fan, has a general inclination in north-eastern to south-western direction (Fig. 7a). We assume that the old mud flow direction was influenced by this inclination.

In contrast, the slope tendency of unit I (Fig. 7b) clearly shows a trend from high topography in the northwest towards low topography in the south-eastern and southern part. Thus, at present the drainage direction of the flat centre (NW to SE) is perpendicular to the general inclination direction of the continental slope (Fig. 7a). Fresh mud flows, seeping from depths of several hundred meters to few kilometers (Eldholm et al., 1999) in the NW of unit I, would preferably follow the detected trend surface into south-eastern and southern direction (Fig. 7a). We suppose that the deposition of former mud flows shaped the morphology and caused the deviation in the direction of the current mud flows.

In the northern part of the central unit I we observed the highest trend surface elevation for unit I, the highest temperature and heat flows (Kaul and Heesemann, 2004), distinct lineations (Fig. 2), and the largest spatial distribution of uncovered mud areas. Therefore, we suggest this sub-region of the HMMV as the suggested source location (sSL) of fresh mud flows (Fig. 9). The recent flows are likely to have been stopped or redirected by the interaction with the hummocky periphery (Fig. 6d).
Based on the spatial analysis (Figs. 6, 7 and 8b) and the hill shading image we assume a temporal relation existing between the colonisation structures of the chemoautotrophic organisms and the flow path of the fresh mud (Figs. 6, 7 and 8b). Fig. 8a and b shows a sequence of elevation profiles based on the microbathymetric data and oriented on the trend surface of unit I. Fig. $8 \mathrm{c}$ presents the typical population sequence at the HMMV along the elevation profile 2 and includes the derived biogeochemical habitats and morphologic zones. The SSL is indicated by uncovered or sparsely covered mud, absence of gas hydrates due to high temperatures and highest elevation of unit I. From this site to the south we observe a zone of highest Beggiatoa density $(>50 \%)$, changing into a zone with a bacteria density of $20-50 \%$ coverage, again changing into a zone with low bacteria density $(0-20 \%)$ combined with a high occurrence of pogonophorans, and finally ending at a zone where only tube worms settle the area of the HCR (Fig. 8c).

Microbial consumption limits the flux and the release of methane through the sediment water interface. Beggiatoa and pogonophorans use primarily hydrogen sulphide resulted from the process of the AOM. If the zone of the AOM is near to the sediment surface, the rate of the sulphide synthesis and the sulphide gradients increases. The highly different vertical sulphide gradients below different communities strongly indicate the important role of sulphide availability in structuring community composition. Thus, high Beggiatoa density points on high AOM rate while pogonophorans indicate 

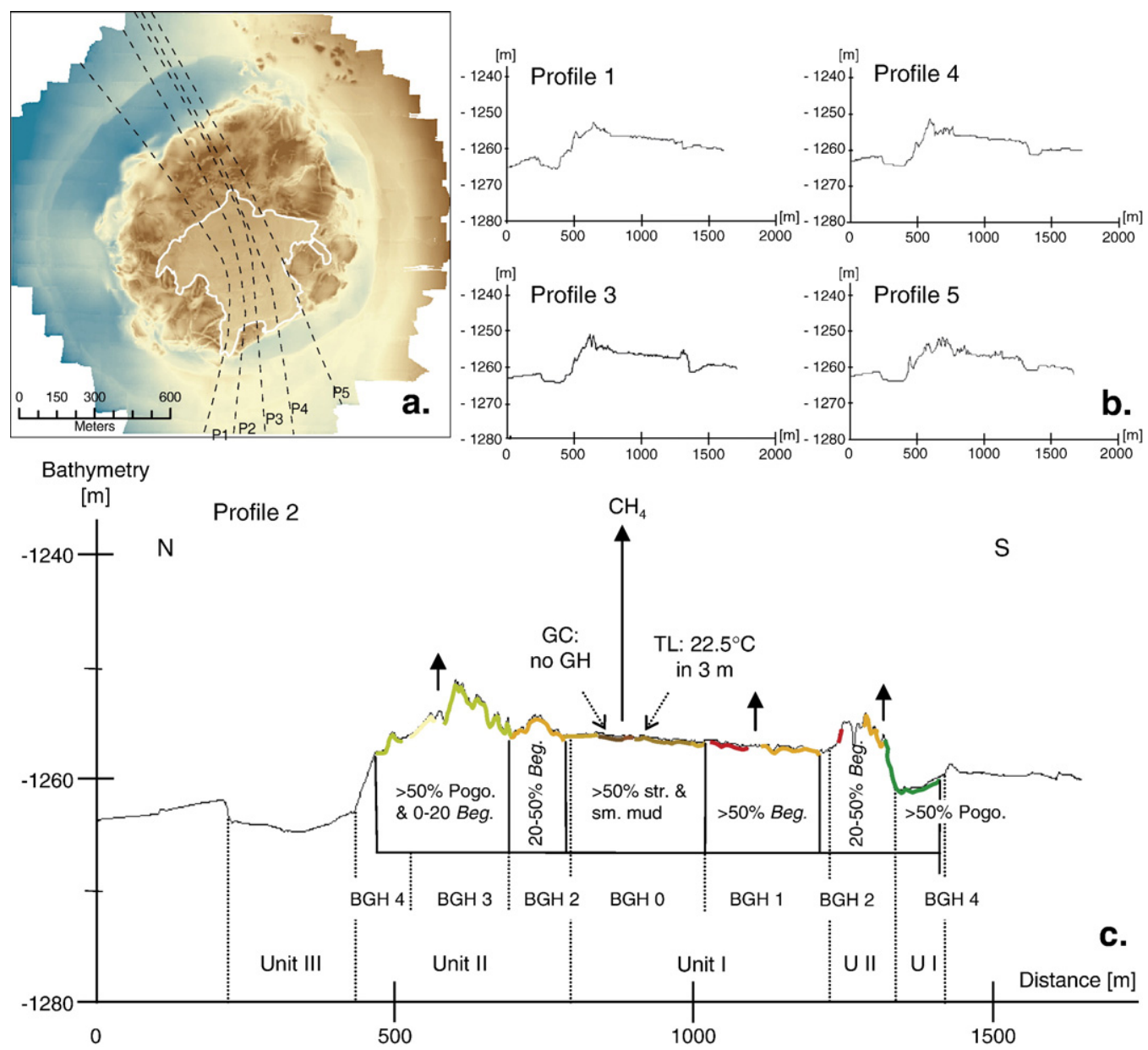

Fig. 8. Elevation profiles. a. Overview of the orientation of five profiles. b. Elevation profiles P1, P3, P4, and P5 from east to west direction. c. Sequences of biogeochemical habitats (BGH) along the elevation profile 2.

$\mathrm{AOM}$ in smaller extent; the tube worms are able to achieve to sulphide from deeper sediment layers than the Beggiatoa (Sahling et al., 2002).

Derived from the occurrence and spatial density of chemoautotrophic communities and uncovered mud areas, we define five biogeochemical habitats (BGH 0-4) represented in Fig. 9.

The central uncovered part, the BGH 0 , is still not recolonisation by Beggiatoa or pogonophorans, thus, one of the youngest mud flows (Fig. 6a). The zone around the SSL of current mud flows, where probably no biofiltering AOM-active microbial consortia in the upper sediment layer occur, we expect as the region of the highest $\mathrm{CH}_{4}$ flux (Fig. 9). This BGH 0 represents $15.6 \%$ of the HCR and $59.8 \%$ of the entire unit I (Fig. 6a). Different processes might be the reason why this central region is still uncovered: (i) not enough time has elapsed since the last mud flow event for re-colonisation by Beggiatoa; (ii) the chemical composition of pore water is still not suitable; and (iii) advective processes or sediment dynamics inhibit archaea development (compared to diffusive methane gradients). We exclude high temperatures as the limiting factor only for Beggiatoa (A. Boetius, pers. comm.); for pogonophorans a negative correlation is more probable (Sahling et al., 2005).

BGH 1 is the region of highest population density by Beggiatoa on the sediment surface. Beggiatoa mats $(>50 \%)$ cover $5.2 \%$ of the HCR or $19.9 \%$ of unit I (Fig. 6c). Where southern and eastern of the BGH 0 bacteria patches of more than $30 \mathrm{~cm}$ in diameter cover areas of up to several square meters, a total absence of pogonophorans is observed. This lobe-shaped area, stretching from the hummocky periphery in the west to the north-east, separates the uncovered mud sequence into a central, western, and southern sub-region (Fig. 6d). Since Beggiatoa and their symbionts are tolerant to high concentrations and steep gradients of 


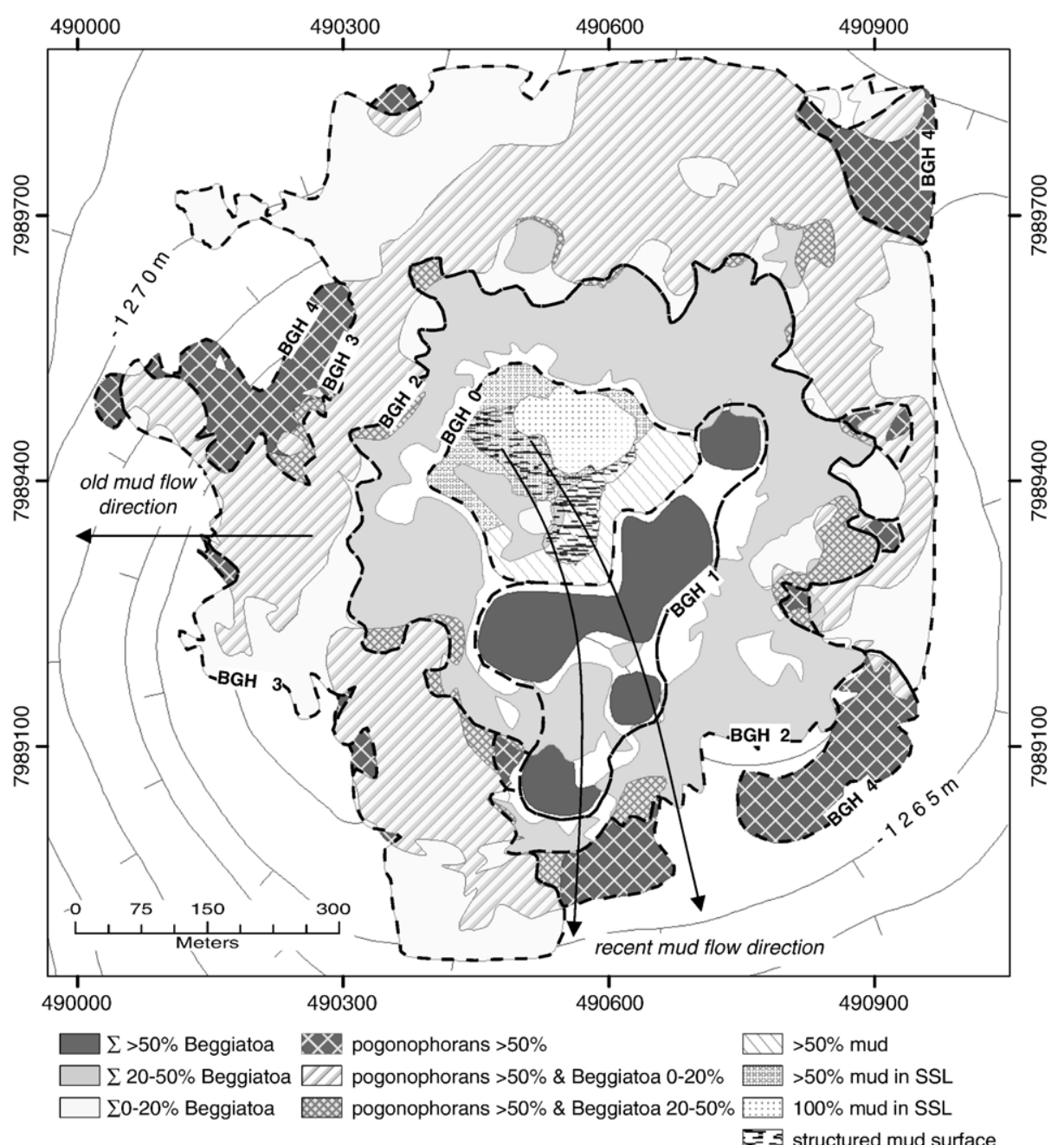

Fig. 9. Schematic map of the major zones of release or anaerobic oxidation of methane. BGH 0 is the region of highest $\mathrm{CH}_{4}$ release, $\mathrm{BGH} 1-4$ are regions of biofiltering communities from high to low $\mathrm{CH}_{4}$ consumption and indicated by occurrence of sulphide-oxidising Beggiatoa and pogonophorans. The suggested source location (SSL) of fresh mud flows is derived from the trend surface analysis, the locations of highest temperature (Kaul and Heesemann, 2004), and the regions of uncovered mud.

reduced chemical components as hydrogen sulphide, this spatial distribution suggests that these organisms are pioneering the fresh mud flows.

The BGH 0 and 1, both located within the flat centre, are enclosed by the BGH 2. This BGH 2 is to be found in parts of the flat centre and in parts of the hummocky periphery and is characterised by a high probability of a bacteria density of $20-50 \%$. Pogonophorans or other macrofauna, dominant in regions of lower rates of methane seepage and hydrogen sulphide formation (Levin et al., 2003; Sahling et al., 2002), were not observed for BGH 2.

BGH 3 is characterised by a rough topography (morphological unit II) and a surface elevation of up to $9 \mathrm{~m}$ with respect to the centre and $16 \mathrm{~m}$ with respect to the moat. Probably, it consists of material of old mud flows and could have been disrupted and pushed aside by the younger mud flows emitted at the centre. This area is mainly covered by pogonophorans (coverage $>50 \%$ ) while the bacteria diminish concentrically towards the periphery (coverage $0-20 \%$ ) building a large transition zone of Beggiatoa and pogonophorans (BGH 3) until the Beggiatoa are completely replaced by the tube worms (BGH 4). In the SSW of the HMMV the BGH 3 the otherwise concentric zone is interrupted in the area of the recent mud flow pathway.

The pogonophoran BGH 4 which is excluding colonised by pogonophorans covers the area along the SSW outflow of the flat area into the moat area (Fig. 9). Apparently, as a consequence of the direction of the 
recent mud flow bacteria and tube worms occur with the largest distance to the suggest source location (SSL) of fresh mud. Beside that, the moat area is apparently free of macro and mega fauna. From this perspective the distribution pattern of chemoautotrophic communities suggests that the last outflow of mud from the HMMV structure occurred through the SE outlet, where no pogonophorans are observed (Fig. 6b). In contrast to the SE outlet, today the outlet located in the south is already colonised by these communities.

The temporal pattern of mud re-colonisation by chemoautotrophic communities can be estimated, therefore, from their spatial distribution along the S and SSW direction pathway (Fig. 8c): observations of Beggiatoa distribution evolving from very localised narrow occurrences (spots) southeast of the uncovered mud area to densely distributed large mats (patches) south and east of the centre (Fig. 6d) might indicate the increasing age of the underlying mud flow.

\section{Conclusions}

Since chemoautotrophic communities as Beggiatoa and pogonophorans indicate efficient "biofiltering" microbial organisms, limiting the release of methane from sediments to the water column, their spatial distribution (Fig. 6) is a suitable detector to distinguish between areas of high versus low methane discharge at the HMMV and other offshore mud volcanoes. The spatial distribution and absolute values - on a $\mathrm{m}^{2}$ basis - for the coverage by these chemoautotrophic communities and mud flows provide therefore a basis for budgets of methane oxidation and of methane release into the water column.

Deducing the position and the alignment of the old mud flow as well as the highest elevation of the unit I the SSL seems to remain locally constant. The recent mud flow, originating from further mud discharge, follows the arising new trend direction toward S and SSW. The combination of accurate navigation as USBL, high resolution bathymetry, and georeferenced video mosaics allows deciphering temporal changes as spreading of mud flows or of Beggiatoa mats and might be able to present a "baseline study" for further analysis of temporal-spatial changes at extreme environments like mud volcanoes.

Our results represent an extension of the distribution pattern described by Gebruk et al. (2003) and Milkov et al. (1999, 2004). Whereas the previous mapping approaches basically used the presence of either pogonophorans, or Beggiatoa, or mud sequences, the co-occurrence of these features (Fig. 6d) as well as the quantification of areas and high resolution bathym- etry allows a more detailed consideration of biogeochemical habitats and their dynamics. Thus, the GIS techniques applied here did not only allow the identification of the active centre, but also support quantification of areas dominated by bacteria, and transition zones, where we expect subsequently decreasing diffusive methane gradients.

The applied video mosaicing analysis is a progress beyond the classical still photograph-approach due to (i) the larger areas covered in two-dimensional manner and (ii) the availability of geographic coordinates for each pixel and therefore each feature at the seafloor. This offers a number of GIS applications to describe the spatial distribution of any kind of object identified in the mosaics, as shown in this study (visual feature detection attached to a certain geographical location, geostatistical interpolation (revisable e.g. by cross-validation, overlay, trend surface analysis)). Geostatistics also provide techniques to identify spatial correlation with other parameters, e.g. to identify the complex colonisation structures which are related to geochemical parameters such as methane and hydrogen sulphide concentration in sediments, occurrence of gas hydrates, seafloor morphology, temperature and the sequence of mud flows. Furthermore, in marine geosciences the image analysis attains more at relevance, due to progressive techniques and amount of data, so automatic feature detection would reduce the labour- and time-intensive visual image inspection.

\section{Acknowledgements}

The authors thank the captain and crew of $R V$ Polarstern and the Genavir team of ROV Victor6000 for their unremitting assistance. We are grateful to the Ifremer colleagues P. Siméoni and L. Méar for the technical support during the video mosaicing surveys. Furthermore, we express our thanks to the AWI colleagues S. Kasten and E. Sauter for the productive comments on an earlier version of the manuscript.

This study was performed in the framework of the R\&D-Programme GEOTECHNOLOGIEN funded by the German Ministry of Education and Research (BMBF) and German Research Foundation (DFG) as well as the AWIIfremer bilateral collaboration programme. This is publication no. GEOTECH-202.

\section{References}

Allais, A.-G., Borgetto, M., Opderbecke, J., Pessel, N., Rigaud, V., 2004. Seabed video mosaicing with MATISSE: a technical overview and cruise results. Proceedings of 14th International Offshore and Polar Engineering Conference, ISOPE-2004, Toulon, France, May 23-28, 2004, vol. 2, pp. 417-421. 
Boetius, A., Ravenschlag, K., Schubert, C.J., Rickert, D., Widdel, F., Gieseke, A., Amann, R., Jørgensen, B.B., Witte, U., Pfannkuche, O., 2000. A marine microbial consortium apparently mediating anaerobic oxidation of methane. Nature 407, 623-626.

Boetius, A., Jørgensen, B.B., Amann, R., Henriet, J.P., Hinrichs, K.U., Lochte, K., MacGregor, B.J., Voordouw, G., 2002. Microbial systems in sedimentary environments of continental margins. In: Wefer, G., Billett, D., Hebbeln, D., Jørgensen, B.B., Schlüter, M., Van Weering, T. (Eds.), Ocean Margin Systems. Springer-Verlag, Berlin-Heidelberg, pp. 479-495.

Boetius, A., Beier, V., Niemann, H., Müller, I., Heinrich, F., Feseker, T., 2004. Geomicrobiology of sediments and bottom waters of the Håkon Mosby Mud Volcano. In: Klages, M., Thiede, J., Foucher, J.-P. (Eds.), The Expedition ARK XIX/3 of the Research Vessel "Polarstern" in 2003. Reports on Polar and Marine Research, vol. 488, pp. 190-199.

Bonham-Carter, G.F., 1996. Geographic Information Systems for Geoscientists: Modelling with GIS. Computer Methods in Geoscience. Pergamon, Ontario. 414 pp.

Clark, I., 1982. Practical Geostatistics. Elsevier Applied Science. 129 pp.

Damm, E., Budéus, G., 2003. Fate of vent-derived methane in seawater above the Håkon Mosby Mud Volcano (Norwegian Sea). Mar. Chem. 82, 1-11.

Davis, J.C., 2002. Statistics and Data Analysis in Geology, 3rd edition. John Wiley and Sons, New York. 638 pp.

De Beer, D., Sauter, E., Niemann, H., Witte, U., Schlüter, M., Boetius, A., 2006. In situ fluxes and zonation of microbial activity in surface sediments of the Håkon Mosby Mud Volcano. Limnol. Oceanogr. 51 (3), 1315-1331.

Dimitrov, L.I., 2002. Mud volcanoes - the most important pathway for degassing deeply buried sediments. Earth-Sci. Rev. 59, 49-76.

Edy, C., Bisquay, H., Foucher, J.P., Opderbecke, J., Simeoni, P., Allais, A.G., Beyer, A., Jerosch, K., Rathlau, R., 2004. Microbathymetry of the Håkon Mosby mud volcano off Northern Norway: results of a ROV-born multibeam survey. European Geosciences Union, Geophysical Research Abstracts, vol. 6. 04619, SRef-ID: 16077962/gra/EGU04-A-04619.

Eldholm, O., Sundvor, E., Vogt, P.R., Hjelstuen, B.O., Crane, K., Nilsen, A.K., Gladczenko, T.P., 1999. SW Barents Sea continental margin heat flow and Håkon Mosby Mud Volcano. Geo-Mar. Lett. 19, $29-37$.

Fleischer, P., Orsi, T.H., Richardson, M.D., Anderson, A.L., 2001. Distribution of free gas in marine sediments: a global overview. Geo-Mar. Lett. 21, 103-122.

Gebruk, A.V., Krylova, E.M., Lein, A.Y., Vinogradov, G.M., Anderson, E., Pimenov, N.V., Cherkashev, G.A., Crane, K., 2003. Methane seep community of the Håkon Mosby Mud Volcano (the Norwegian Sea): composition and trophic aspects. Sarsia 88, 394-403.

Ginsburg, G.D., Milkov, A.V., Soloviev, V.A., Egorov, A.V., Cherkashev, G.A., Vogt, P.R., Crane, K., Lorenson, T.D., Khutorskoy, M.D., 1999. Gas hydrate accumulation at the Håkon Mosby Mud Volcano. Geo-Mar. Lett. 19, 57-67.

Goovaerts, P., 1997. Geostatistics for Natural Resources Evaluation. Oxford University Press, New York. 496 pp.

Hinrichs, K.U., Boetius, A., 2002. The anaerobic oxidation of methane: new insights in microbial ecology and biogeochemistry. In: Wefer, G., Billett, D., Hebbeln, D., Jørgensen, B.B., Schlüter, M., Van Weering, T. (Eds.), Ocean Margin Systems. SpringerVerlag, Berlin-Heidelberg, pp. 457-477.

Hjelstuen, B.O., Eldholm, O., Faleide, J.I., Vogt, P.R., 1999. Regional setting of Håkon Mosby Mud Volcano, SW Barents Sea margin. Geo-Mar. Lett. 19, 22-28.

Huguen, C., Mascle, J., Chaumillon, E., Kopf, A.J., Woodside, J., Zitter, T., 2004. Structural setting and tectonic control of mud volcanoes from the Central Mediterranean Ridge (Eastern Mediterranean). Mar. Geol. 209 (1-4), 245-263.

Isaaks, E.H., Srivastava, R.M., 1992. An Introduction to Applied Geostatistics. Oxford University Press. $561 \mathrm{pp}$.

Ivanov, M.K., Limonov, A.F., Van Weering, T., 1996. Comparative characteristics of the Black Sea and Mediterranean Ridge mud volcanoes. Mar. Geol. 132, 253-271.

Jerosch, K., Schlüter, M., Pesch, T., 2006. Indicator kriging applied for video mosaics: a case study of habitat mapping at the deep-sea submarine Håkon Mosby Mud Volcano. Ecological Informatics 1, 391-406.

Kaul, N., Heesemann, B., 2004. Heat probe measurements down to $3 \mathrm{~m}$ depth. In: Klages, M., Thiede, J., Foucher, J.-P. (Eds.), The Expedition ARK XIX/3 of the Research Vessel "Polarstern" in 2003. Reports on Polar and Marine Research, vol. 488, pp. 164-169.

Klages, M., Thiede, J., Foucher, J.-P., 2004. The Expedition ARK XIX/3 of the Research Vessel "Polarstern" in 2003. Reports on Polar and Marine Research, vol. 488. 346 pp.

Kohl, B., Roberts, H.H., 1994. Fossil foraminifera from four active mud volcanoes in the Gulf of Mexico. Geo-Mar. Lett. 14, $126-134$.

Kopf, A.J., 2002. Significance of mud volcanism. Rev. Geophys. 40 (2), 1005. doi:10.1029/2000RG000093.

Lein, A., Vogt, P.R., Crane, K., Egorov, A., Ivanov, M., 1999. Chemical and isotopic evidence for the nature of the fluid in $\mathrm{CH}_{4}$ containing sediments of the Håkon Mosby Mud Volcano. GeoMar. Lett. 19, 76-83.

Levin, L.A., Ziebis, W., Mendoza, G.F., Growney, V.A., Tryon, M.D., Brown, K.M., Mahn, C., Gieskes, J.M., Rathburn, A.E., 2003. Spatial heterogeneity of macrofauna at northern California methane seeps: influence of sulphide concentration and fluid flow. Mar. Ecol. Prog. Ser. 265, 123-139.

Mienert, J., Posewang, J., 1999. Evidence of shallow- and deep-water gas hydrate destabilizations in North Atlantic polar continental margin sediments. Geo-Mar. Lett. 19, 143-149.

Milkov, A.V., 2000. Worldwide distribution of submarine mud volcanoes and associated gas hydrates. Mar. Geol. 167, 29-42.

Milkov, A.V., Vogt, P.R., Cherkashev, G., 1999. Sea-floor terrains of Håkon Mosby Mud Volcano as surveyed by deep-tow video and still photography. Geo-Mar. Lett. 19, 38-47.

Milkov, A.V., Sassen, R., Apanasovich, T.V., Dadashev, F.G., 2003. Global gas flux from mud volcanoes: a significant source of fossil methane in the atmosphere and the ocean. Geophys. Res. Lett. 30 (2), 9/1-9/4.

Milkov, A.V., Vogt, P.R., Crane, K., Lein, A.Y., Sassen, R., Cherkashev, G.A., 2004. Geological, geochemical, and microbial processes at the hydrate-bearing Håkon Mosby mud volcano: a review. Chem. Geol. 205, 347-366.

Pimenov, N., Savvichev, A., Rusanov, I., Lein, A., Egorov, A., Gebruk, A., Moskalev, L., Vogt, P., 1999. Microbial processes of carbon cycle as the base of food chain of Håkon Mosby Mud Volcano benthic community. Geo-Mar. Lett. 19, 89-96.

Pimenov, N.V., Savvichev, A.S., Rusanov, I.I., Lein, A.Y., Ivanov, M.V., 2000. Microbiological processes of the carbon and sulphur cycles at cold methane seeps of the North Atlantic. Microbiology 69, 709-720.

Rivoirard, J., Wieland, K., 2001. Correcting for the effect of daylight in abundance estimation of juvenile haddock (Melanogrammus aeglefinus) in the North Sea: an application of kriging with external drift. ICES J. Mar. Sci. 58, 1272-1285.

Sahling, H., Rickert, D., Lee, R.W., Linke, P., Suess, E., 2002. Macrofaunal community structure and sulfide flux at gas hydrate 
deposits from the Cascadia convergent margin, NE Pacific. Mar. Ecol. Prog. Ser. 231, 121-138.

Sahling, H., Wallmann, K., Dählmann, A., Schmaljohann, R., Petersen, S., 2005. The physicochemical habitat of Sclerolinum sp. at Hook Ridge hydrothermal vent, Bransfield Strait, Antarctica. Limnol. Oceanogr. 50 (2), 598-606.

Sauter, E.J., Muyakshin, S.I., Charlou, J.-L., Schlüter, M., Boetius, A., Jerosch, K., Damm, E., Foucher, J.-P., Klages, M., 2006. Methane discharge from a deep-sea submarine mud volcano into the upper water column by gas hydrate-coated methane bubbles. Earth Planet. Sci. Lett. 243, 354-365.

Schlüter, M., 1996. Einführung in geomathematische Verfahren und deren Programmierung. Enke Verlag, Stuttgart. 326 pp.

Sibuet, M., Olu, K., 1998. Biogeography, biodiversity and fluid dependence of deep-sea cold-seep communities at active and passive margins. Deep-Sea Res. II 45, 517-567.

Sibuet, M., Olu-Le Roy, K., 2002. Cold seep communities on continental margins: structure and quantitative distribution relative to geological and fluid venting patterns. In: Wefer, G., Billett, D., Hebbeln, D., Jørgensen, B.B., Schlüter, M., Van Weering, T. (Eds.), Ocean Margin Systems. Springer-Verlag, Berlin-Heidelberg, pp. 235-251.
Smirnov, R.V., 2000. Two new species of pogonophoran from the Arctic mud volcano off northwestern Norway. Sarsia 85, 141-150.

Soltwedel, T., Portnova, D., Kolar, I., Mokievsky, V., Schewe, I., 2005. The small-sized benthic biota of the Håkon Mosby Mud Volcano (SW Barents Sea slope). J. Mar. Syst. 55, 271-290.

Vincent, A.G., Jouffroy, J., Pessel, N., Opderbecke, J., Borgetto, M., Rigaud, V., 2003. Real-time georeferenced video mosaicing with the MATISSE system. Proceedings of the Oceans 2003 Marine Technology and Ocean Science Conference, MTS/IEEE OCEANS'03, San Diego, USA, September 22-26, 2003, vol. 4, pp. 2319-2324.

Vogt, P.R., Cherkashev, G., Ginsburg, G., Ivanov, G., Milkov, A., Crane, K., Lein, A., Sundvor, E., Pimenov, N., Egorov, A., 1997. Håkon Mosby Mud Volcano provides unusual example of venting. EOS 78 (549), 556-557.

Vogt, P.R., Gardner, J., Crane, K., 1999. The Norwegian-BarentsSvalbard (NBS) continental margin: introducing a natural laboratory of mass wasting, hydrates and ascent of sediment pore water and methane. Geo-Mar. Lett. 19, 2-21. 